Global Sustainability

cambridge.org/sus

\section{Intelligence Briefing}

Cite this article: Benton TG, Bailey R (2019). The paradox of productivity: agricultural productivity promotes food system inefficiency. Global Sustainability 2, e6, 1-8. https://doi.org/10.1017/sus.2019.3

Received: 5 July 2018

Revised: 25 March 2019

Accepted: 29 March 2019

Keywords:

agriculture; efficiency; environmental costs; health costs; trade

Author for correspondence: T. Benton, E-mail: t.g.benton@leeds.ac.uk; tbenton@ chathamhouse.org

\title{
The paradox of productivity: agricultural productivity promotes food system inefficiency
}

Tim G. Benton ${ }^{1,2}$ and Rob Bailey ${ }^{1}$

${ }^{1}$ Energy, Environment and Resources Department, The Royal Institute of International Affairs, Chatham House, 10 St James's Square, London SW1Y 4LE, UK and ${ }^{2}$ School of Biology, University of Leeds, Leeds, LS2 9JT, UK

\section{Non-technical summary}

The principal policy focus for food has been to increase agricultural productivity and to liberalize markets allowing globalized trade. This focus has led to huge growth in the supply of agricultural produce, more calories becoming available, and price declining. The availability of cheaper calories increasingly underpins diets creating malnourishment through obesity, and global competition incentivizes producers who can produce the most, cheaply, typically with environmental damage. We propose re-focusing, away from yields per unit input, to the food system's overall productivity and efficiency - the number of people that can be fed healthily and sustainably per unit input.

\section{Technical summary}

Since the Second World War, and particularly in recent decades, the over-arching rationale of agricultural and food trade policy has been that by increasing the productivity of agriculture and efficiency of its markets, trade will drive down food prices, drive up choices and food availability: implicitly defining more available and cheaper food as the route to achieving the international public good of global food security. Here we hypothesize that a focus on increasing availability of food, and lowering food prices through focusing on agricultural productivity and trade does reduce prices and increases availability, but also encourages the externalization of costs on health and environment, and instead of providing public goods arguably represents market failure. In other words, a focus on increasing agricultural yields and efficiency decreases the efficiency of the food system through incentivizing externalization of costs. The focus should rather be on the efficiency of the food system to deliver profits, healthy diets and a healthy planet. Reframing the productivity argument towards the efficiency of the food system provides a clear route to reducing market failure, improving public health and sustainability.

Today, global agriculture is more productive and efficient than ever. Since the 1960s, global agricultural output has risen enormously (Alexandratos, \& Bruinsma, 2012). Whilst the global population has risen by $142 \%$ since 1961 (to 2016), average cereal yields increased by a factor of $193 \%$ and calorie production by a factor of $217 \%$ (to 2013) . $^{\mathrm{i}}$. Underpinning this increase in production was an increase in technical efficiency given that arable land area increased by only $10 \%$. This is borne out by the trend in total factor productivity (TFP: food output weighted by economic inputs), which provides a common measure of agricultural efficiency and increased by $0.93 \%$ per year during the period 1961-2012 (Fuglie, 2015). Over the same time period, the World Bank food price index ${ }^{\mathrm{ii}}$ trended downwards, declining by $37 \%$ in real terms. As the US Department of Agriculture observed, "Over the past 50 years, productivity growth in agriculture has allowed food to become more abundant and cheaper"iii (Figure $1 \mathrm{~A} \& \mathrm{~B}$ ).

Yet at the heart of this remarkable achievement lies a paradox: as the efficiency of production has increased, the efficiency of the food system as a whole - in terms of delivering nutritious food, sustainably and with little waste - has declined. Yield growth and falling food prices have been accompanied by increasing food waste, a growing malnutrition burden and unsustainable environmental degradation. These consequences arise from deliberate policy choices in the past.

(c) The Author(s) 2019. This is an Open Access article, distributed under the terms of the Creative Commons Attribution licence (http:// creativecommons.org/licenses/by/4.0/), which permits unrestricted re-use, distribution, and reproduction in any medium, provided the original work is properly cited.

\section{CAMBRIDGE UNIVERSITY PRESS}



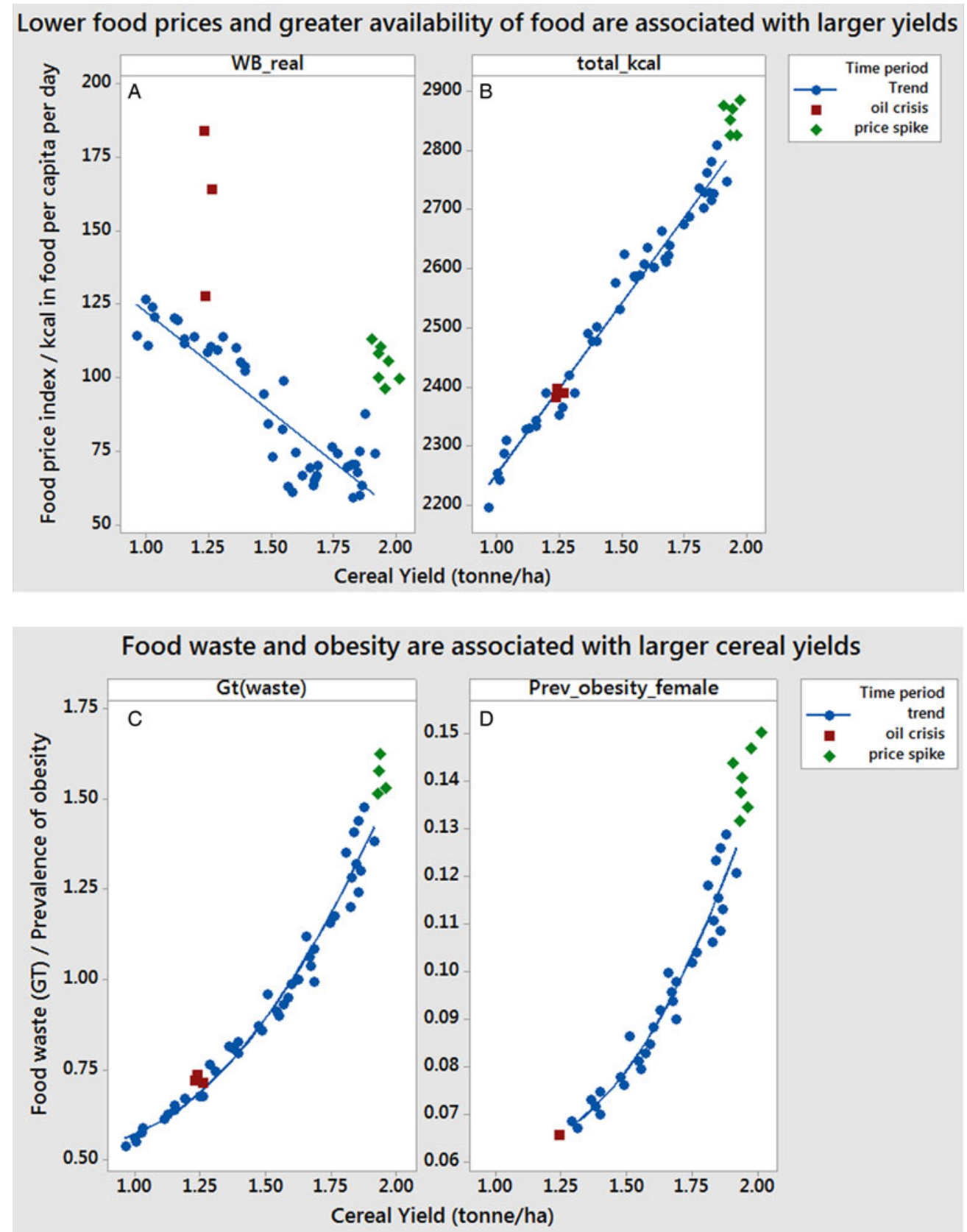

Fig. 1. The relationship between average global cereal yields (as a proxy for agricultural productivity), food price and availability, food waste and obesity. (A) As yields (tonne/ha) increase, on average food prices decline linearly. Data are from the World Bank and FAOSTAT. The colour codes represent 'normal' or 'trend' (blue), the 1970s oil crisis (red) and the period from the 2007 food price spike (green). (B) As yields increase, the calories available per person on a global basis increases linearly. (C) As yields increase, price decreases and availability increases, the amount of food wasted globally increases in an accelerating way, as does the global prevalence of obesity in adult females, suggesting an accelerating increase in per capita consumption (D). Data from FAOSTAT (cereal production divided by area of cultivation), the World Bank (deflated food price index), waste data from (Porter et al., 2016) and obesity data from (NCD-RisC, 2016a). The fitted lines are simple least-squares regressions fitted to the blue dots, with best fits being linear $(A, B)$ and quadratic $(C, D)$. The trend lines are: $(A)$ WB_real $=190.3-$ $67.86^{\star}$ cereal trend (adjusted $R^{2}=80.2 \%$ ); (B) total_kcal $=1682+574.1^{\star}$ cereal trend (adjusted $R^{2}=97.3 \%$ ); (C) Gt $\left(\right.$ waste) $=0.9813-1.107^{\star}$ cereal trend $+0.6977^{\star}$ cereal trend $^{2}$ (adjusted $R^{2}=96.9 \%$ ); (D) Prev_obesity_female $=0.1673-0.1913^{\star}$ cereal trend $+0.08849^{\star}$ cereal trend ${ }^{2}$ (adjusted $R^{2}=90.6 \%$ ).

of the world, through their own efforts, to produce more food, more clothing, more materials for housing, and more mechanical power to lighten their burdens."

Multilateral trade liberalization progressed through the General Agreement on Tariffs and Trade, which evolved into the World Trade Organization in 1995. To promote yield growth, and to protect their farm sectors from the full effects of increasing global competition brought about by trade, developed country governments invested heavily in agricultural subsidies which persist today. Data available in 2012-2014, for 52 countries responsible for approximately two thirds of global agricultural value, suggest $\$ 519$ billion of support was given per annum to agriculture (OECD, 2017).

The Green Revolution - an international donor-led research and development programme to create and adopt high-yielding varieties of maize, wheat and rice and intensive agricultural 
practices - led to remarkable yield growth throughout Asia and Latin America, underpinning the ability of developing country agriculture to link to international commodity markets. Across the developing world, trade liberalization was prescribed through the technical assistance and structural adjustment programmes of the World Bank and International Monetary Fund as part of the 'Washington Consensus' (Williamson, 1990): opening up markets to international competition was a common funding condition.

Underpinned by both trade liberalization and investment in productivity growth, trade in agricultural products, food and its ingredients grew exponentially from the 1960s, such that by $2008,60 \%$ of the total value of food was traded internationally (\$1060/\$1780 billion) (Ercsey-Ravasz et al., 2012).

Thus, the joint investments in productivity growth and international trade (creating globally competitive markets), led to the long run decline in international food prices described earlier (Figure 1), and provided a powerful justification for these policies on the basis that cheaper food provides social benefits.

\section{Cheaper food as a public good}

For governments, concerned with the security and welfare of their populations, cheaper food enhances food accessibility (one of the four dimensions of food security in a widely used definition). And given the relationship between food price inflation and social unrest, politicians often view low (or lowering) food prices as important not only for food security, but also political security. More broadly, falling food prices relative to incomes is seen as an essential component of economic development, as it can provide more disposable income for purchasing other goods, and thus drive more economic activity.

For economists, argued by Dorward (2013), in the long run low and stable food prices meet the definition of 'public goods' because they are non-excludable and non-rival benefits arising from government investment in agricultural research. In other words, low food prices facilitated by public investment in agricultural productivity provide benefits to everyone through higher disposable incomes (via lower food bills), avoided negative impacts on the welfare of poor consumers, and wider associated development gains that occur as a result. Cheaper and more available food also arises as an externality from commercial research investments in excludable technologies, as well as from producers' and traders' decisions to produce and sell food.

The notion of cheaper food being important because it provides food security by allowing access to food at all times by all people is thus further supported by the notion that by reducing food prices allows more money for people to spend on other goods, driving the economy further. Promoting consumption growth for the benefit of the economy has been an underpinning notion for decades. In the 1950s the US marketer, Victor Lebow, famously said:

\footnotetext{
"Our enormously productive economy demands that we make consumption our way of life, that we convert the buying and use of goods into rituals, that we seek our spiritual satisfactions, our ego satisfactions, in consumption. The measure of social status, of social acceptance, of prestige, is now to be found in our consumptive patterns. The very meaning and significance of our lives today expressed in consumptive terms ... in terms of what he wears, drives, eats - his home, his car, his pattern of food serving, his hobbies..."
}

We need things consumed, burned up, worn out, replaced, and discarded at an ever increasing pace. We need to have people eat, drink, dress, ride, live, with ever more complicated and, therefore, constantly more expensive consumption." (Lebow, 1955, p. 7).

The support for consumption growth to drive the economy must, in the long run, be balanced against any costs that growing consumption might impose on public health and environmental systems.

\section{Increasingly productive and efficient production has downsides}

As economic theory predicts, policies supporting agricultural efficiency and productivity, coupled with trade liberalization to increase market competitiveness, have increased food availability and driven down prices (Figure 1A \& B). This has in part come about through specialization of production: global agriculture has become increasingly focused on a few highly productive commodity crops suited to industrial farming systems and grown at scale in the 'breadbasket' areas of the world. These staples have crowded out alternative, traditionally grown varieties and attracted the lion's share of crop-related R\&D. Over 50\% of the world's crop calories now come from wheat, rice and maize; adding sugar, barley, soy, palm and potato gets to $76 \%$ (West et al., 2014). This has a number of implications.

First, calorie production is concentrated genetically and geographically, creating a potentially fragile global food system vulnerable to disruptions in breadbaskets or to pests and diseases affecting key staples (Puma et al., 2015). Second, the increasing dominance of these energy-dense staples in global food supply has contributed to the growth in obesogenic processed foods, as food manufacturers have formulated products derived from these abundant, low-cost, high-calorie commodities. Third, the growth in food trade and manufacturing has led to long and complex supply chains that create challenges of transparency, traceability and food safety (Ercsey-Ravasz et al., 2012; Puma et al., 2015). Fourth, the growth in availability of animal feeds derived from commodity staples - notably soybean and coarse grains has underpinned the exponential growth of the livestock sector and the associated growth in meat and dairy consumption.

Together, the system that specializes in producing cheaper, more available, calories, has led to significant costs levied on health systems from inadequate diets, and on the environment via production, manufacturing, processing and waste management. There is now growing evidence, as suggested below, that the costs from dietary-related ill health and environmental degradation exceed the economic value of agriculture, raising the alarming prospect that the full costs to society of food production may outweigh the benefits.

\subsection{A growing public health burden}

The initial focus on yield growth and the green revolution was motivated, in part, by reducing hunger through increasing availability of food and, to some extent, this has been successful. The proportion of people undernourished has declined over time (NCD-RisC, 2016a). However, there have also been less benign consequences for nutrition. Across the world diets have become more similar as eating habits have converged on foods underpinned by the same commodities (Khoury et al., 2014), arising from global agriculture's bias towards energy-dense commodities rather than nutrient-rich fruits and vegetables (Bahadur et al., 2018). Consequently, whilst hunger and underweight are 
Tim G. Benton and Rob Bailey

decreasing, malnutrition in all its forms, including obesity, is growing. As calories have become cheaper (Figure 1A) and more available (Figure 1B), more people have become overweight and obese (Figure 1D). Now, only approximately $50 \%$ of the global population is of a healthy weight (NCD-RisC, 2016a), and the prevalence of obesity in the global population has now surpassed the prevalence of underweight (NCD-RisC, 2016a).

The obesity pandemic has immense public health costs. Non-communicable diseases associated with overweight and obesity (Wagner, \& Brath, 2012) include diabetes (NCD-RisC, 2016b), dementia (Hugenschmidt, 2016), cardiovascular disease and a range of cancers. This human health burden is also intergenerational: children of obese mothers having higher propensity to develop diabetes (Cordero et al., 2016). As obesity prevalence grows, so does its economic cost. Estimates of the total healthcare costs of malnutrition are patchy, but the FAO suggested in 2013 that healthcare costs from poor diets might exceed 5\% GDP (FAO, 2013). This may be an underestimate as, given the UK costs of type II diabetes, scaling up to the global projected 700 million people with diabetes in 2025 (NCD-RisC, 2016b), diabetes' direct costs would amount to $4-5 \%$ of GDP. In comparison, the global agricultural added value to GDP was $3.79 \%^{\mathrm{v}}$ in 2015 . Poor diets, especially through over-consumption of calories are becoming a significant global economic drag, exceeding the economic benefit arising from primary agriculture.

\subsection{Increasing environmental degradation}

Incentives for production, global competition based on price, and long supply chains that reduce transparency, together encourage the externalization of production costs on the environment. If economic benefits arise from producing more in a competitive market, there is an incentive to maximize production rather than optimize it for long-term sustainability. Externalized environmental costs include degradation of soils (Amundson et al., 2015), biodiversity loss (Newbold et al., 2016), unsustainable use and pollution of water (Liu et al., 2012; Dalin et al., 2017) and driving climate change, where agri-food emits as much as $30 \%$ of global greenhouse gases (Bajželj et al., 2013). In this context, the growth of the livestock sector, underpinned by production growth, and more affordable feed crops, is particularly noteworthy as a source of environmental degradation (including its contribution to climate change) and competition for resources such as land and water (Eshel et al., 2014; Poore, \& Nemecek, 2018).

As a result of the incentives to externalize costs to produce 'more for less', the environmental costs of agriculture exceed the market value of production (FAO, 2015). For example, the costs of air pollution alone on human health from US agricultural production amount to about half its value (Paulot, \& Jacob, 2014). Data suggest that, for every person on the planet, on average $284 \mathrm{~g}$ of pesticide active ingredient was used in $2015^{\mathrm{vi}}$, $9 \mathrm{~g}$ of antimicrobials in 2010 (Van Boeckel et al., 2015), and 15kg of nitrogen fertilizer (Davis et al., 2016). A globally competitive market favours production efficiency in the form of large-scale, intensive farming. Agriculture that does not produce food without externalizing costs through scale (and landscape homogenization) or inputs, such as pesticides or fertilizers, struggles to be competitive in the market. The incentives to externalize costs may be further exacerbated through public subsidies for production or factors of production such as water, energy or fertilizers.

\subsection{Increasing waste}

As productivity growth and global competition have driven food prices downward, the economic incentive to avoid food waste has declined: as yields grow, waste grows faster (Figure 1C) (Porter et al., 2016). The increasing use of crops for feed in intensive livestock systems results in a further form of inefficiency through trophic losses, with over a third of global calories being used as feed (Cassidy et al., 2013). Whilst livestock produce can be a highly efficient source of nutrients, increasing consumption of livestock produce (above dietary needs) can be seen as a form of inefficiency as potential human food is diverted to feed before being converted to food (Shepon et al., 2016; Alexander et al., 2017).

\section{The paradox of productivity}

If the efficiency of the food system is related to the amount of food grown that is eaten by humans, then, in total, global food system efficiency is $41 \%$ on an energy basis or $36 \%$ on a protein basis, primarily due to food loss and waste. If one includes human over-consumption as an inefficiency, these decline to 38 and $28 \%$, respectively (Alexander et al., 2017). If one considers the trophic losses of eating meat protein versus vegetable protein as a form of inefficiency, the 'opportunity food losses' relative to plant-based food of beef, pork, dairy, poultry, and eggs are a further 96, 90, 75, 50, and 40\%, respectively (Shepon et al., 2018). In simple terms, if there was less waste and people ate more in line with dietary recommendations, it would be possible to free up very significant natural resources and reduce agriculture's impact on both environment (land, water, climate) and health (Harwatt et al., 2017; Bahadur et al., 2018; Poore, \& Nemecek, 2018; Shepon et al., 2018).

Paradoxically, the current systemic inefficiency is a consequence of the drive for efficiency at the farm level: agricultural productivity and competition through trade keeps prices low, making waste economically rational for many consumers, and it creates a market-led focus on high-energy staples, encouraging the inefficient use of crops for animal feed, and the overconsumption of calories by humans. Incentives for agricultural efficiency and productivity - whether through market competition or public support - encourage the externalization of costs onto environment and health systems, costs which exceed by some margin the value of the agricultural economy.

The global food system evolved out of a need to drive consumption on a global basis, at a time when lack of access to food was a real issue and environmental degradation was not. The situation now has changed. Malnutrition from overconsumption of calories affects more people than undernutrition, whilst agriculture has come to threaten the ecosystems on which it depends. On current trends, fulfilling 'business as usual' projections for food demand would create sufficient warming to exceed the goals of the Paris Climate Agreement (Bajzelj et al., 2014), and it is clear that the Sustainable Development Goals (SDGs) cannot be achieved if the strategy for meeting the zero hunger goal (SDG 2 ) is premised on agricultural intensification, as this is likely to undermine the goals associated with land (SDG 15), water (SDG 6), climate (SDG 13), sea (SDG 14) and health (SDG 3). Rather, meeting global goals, whether the SDGs or those of the Paris Agreement, will require a shift in emphasis away from agricultural efficiency to system efficiency.

Despite this, policy remains preoccupied with agricultural productivity and efficiency, through maximizing the growth rate 
of TFP. This is often interpreted as a framing of 'sustainable intensification' (Baulcombe et al., 2009; Garnett et al., 2013) also described as 'growing more with less.' This is a prominent feature of agricultural policies in the major international institutions. ${ }^{\text {vii }}$ But TFP measures the efficiency of food production with respect to the familiar economic inputs of labour, capital, land and chemicals, and fails to capture inputs of natural capital or further costs such as those externalized onto healthcare systems. So whilst increasing TFP remains the prevailing objective of agricultural policymaking, the efficiency paradox is likely to persist.

A better metric would be total resource productivity, or TRP, which extends TFP to include inputs of natural capital (Fuglie et al., 2016) and so provides a measure of sustainable productivity. Conceptually, such a measure could be further extended to include as inputs other externalized costs such as the healthcare costs associated with agricultural production (e.g. via air quality) or from dietary-related ill health, or the costs associated with disposal of food waste and packaging; the outputs, rather than being yield, could be the number of people nourished. This would measure total system productivity (TSP).

A food system with high TSP would be sufficiently productive (to meet human nutritional needs) whilst imposing few costs on the environment and society (so being sustainable), and highly efficient at all stages of the food chain so as to minimize waste. It would optimize total resource inputs (direct inputs and indirect inputs from natural capital and healthcare) relative to the outputs (food utilization). Maximizing TSP would maximize the number of people fed healthily and sustainably per unit input (direct and indirect). In other words, it would increase overall systemic efficiency.

Instead, the focus on agricultural efficiency, defined in terms of TFP, drives a vicious circle. The more we produce, the cheaper food becomes, and the more our diets become obesogenic. Cheaper food requires intensive agriculture, at scale. This undermines natural capital and increases resource competition, resulting in further intensification and extensification as a means to alleviate pressure on resources and compensate for depleted ecosystem services. Greater intensification leads to more greenhouse gas emissions from increased energy and agrochemical use, in addition to those from the growing livestock sector and land expansion. Extensification means more land conversion and its environmental consequences. Climate change further intensifies pressure on land because it both affects yields (and their resilience) and increases the need for land-based carbon sequestration - for example through afforestation and reforestation, or through negative emissions technologies such as bioenergy with carbon capture and storage. The end result is more degradation, more waste, more ill-health from overweight and obesity.

Contrast this with the prospect of a virtuous circle in which the policy objective is the maximization of TSP, and incentives encourage the delivery of healthy diets, sustainably and efficiently. People eat a wider range of produce and eat less and waste less. Dietary diversity improves nutrition and drives agricultural diversity, creating the opportunity for circular and multifunctional landscapes to re-emerge that foster biodiversity. As health bills go down, money is potentially freed up to incentivize more sustainable agriculture, and, as the system becomes more efficient, in particular from reduced waste and livestock production, land is freed up for nature and climate mitigation. The end result would be a healthier planet, and healthier people.

\section{From public good to market failure: the need for new policy}

Once the true costs of a global food system predicated on agricultural productivity and low food prices are recognized, further pressure to lower food prices can no longer be perceived as a public good. Rather, by incentivizing the production of agricultural products, for private benefit, through the externalization of costs on the environment and society, the global food system creates a massive market failure (Rocha, 2007). This provides a clear justification for corrective government intervention, to ensure markets efficiently use society's resources (natural capital and public money) to produce social outcomes (in this case improving public health through nutrition).

To move from vicious to virtuous circles, there are numerous policy levers available. This is not to say it is only public policy that can drive change, but there is a clear rationale for government action to correct market failures and to enable people to eat nutritiously and sustainably. Opportunities are discussed in the following sections.

\subsection{New framings}

Many of the issues discussed are enabled by holistic, crossdisciplinary, cross-sectoral framings of the issues. Such systemic approaches are difficult, because the more systemic the approach the greater range of expertise is required, and the more complex it seems. Nonetheless, societal grand challenges are systemic, and require both transdisciplinary underpinning research and crosssectoral, cross-government policy alignment if we are to identify the intervention points and address them. Increasing our capacity to tackle the difficulties of researching or governing complex, inter-connected, socio-economic-environmental challenges is key.

\subsection{Internalizing externalities}

Correcting the food system's market failures requires interventions to incorporate social and environmental costs into food prices. This implies that food becomes more expensive on average, increasing incentives to reduce waste. But it is also regressive, as poor households spend a higher proportion of income on food. This does not justify inaction however. Continuing the externalization of costs in the name of the poor simply reduces intergenerational equity and does nothing to reduce the impact of poor diet on the health of current generations (Tait, 2015). Compensating policies such as social protection can be applied to insulate poor consumers from adverse welfare impacts.

\subsection{Leading the debate}

Internalizing externalities and increasing food prices will clearly require public acceptance that a reliance on some foods provides costs levied elsewhere. This, in itself, suggests the need for a strong agenda built around creating transparency in the consequences of food choices, education and awareness raising, empowering people to value the sorts of food that provides positive impacts on health and environment. But whilst governments remain silent on food systems and their associated health and environmental costs, people are licensed to ignore the issues. Focus group work indicates it is necessary for governments to contribute to the debate to sensitize people that the issues are important, and 
to lay the ground for future interventions ranging on a spectrum from nudges to Pigovian taxes and regulatory measures (Bailey et al., 2014).

\subsection{Rebalancing subsidies}

As already noted, government intervention in agriculture is significant; however, in much of the world, the bulk of agricultural subsidies incentivize commodity crop production, driving system inefficiency and externalities (McKeon, 2014). A proportion of this support could be used to make nutritious foods competitive with more caloric foods. Subsidies could be used to incentivize production of alternative crops, thus increasing heterogeneity in food supply, and to encourage consumption of more nutritious foods.

\section{Transforming the food system}

Optimizing food system efficiency implies a fundamental transformation of the way in which the global food system is organized. Government interventions to increase agricultural and dietary diversity and include social and environmental costs in market prices can help enable such a transformation, but do not address the configuration of the food system itself, which is shaped not only by existing policies and institutions, but also by incumbent interests, social norms and cultural values.

The literature indicates that systemic transformation often starts from niches - technological, social or institutional innovations that embody new visions for how societal needs can be met. Once these reach critical mass they become mutually reinforcing and change occurs rapidly (Jänicke, \& Jacob, 2004). Where might such niches emerge in the current food system?

\subsection{New norms}

Lifestyle choices such as veganism, vegetarianism and flexitarianism are experiencing rapid growth in developed economies ${ }^{\text {viii }}$. Consumer preferences for food that has been produced locally or for which provenance is clear have also increased ${ }^{\text {ix }}$. Whilst these trends are certainly niche, they are reinforced by growing awareness of the links between diet, health and the environment.

\subsection{New business models}

Enabled by digital technologies, a new generation of companies threatens to disrupt conventional food retail with business models that offer new opportunities to improve system efficiency. Meal kit companies offer customers regular deliveries of measured ingredients and recipes according to their dietary preferences, enabling time poor households to cook meals from whole foods with minimal food waste. Another breed of online retailer is seeking to disintermediate supermarkets by linking consumers to local farmers and food producers, responding to demands for traceability and localism. Blockchain technology will enable businesses to demonstrate provenance and verified sustainability to customers at low cost.

\subsection{New food technologies}

In response to emerging consumer norms, new, more sustainable alternatives to conventional animal protein are being developed such as cultured meat and innovative plant-based meat substitutes that mimic the characteristics of meat products.

\subsection{New financial incentives}

Growing awareness of climate risks in the financial sector is leading to new risk management approaches, new disclosure requirements and the emergence of 'no go' sectors such as coal, ${ }^{\mathrm{x}}$ whilst sustainable finance products and instruments such as green investment funds and green bonds are experiencing rapid growth. Given that the food system accounts for almost a third of greenhouse gas emissions and is a primary driver of biodiversity loss and pollution, it is likely to become an increasing focus of innovation in financial governance and products.

These emerging niches are clearly mutually reinforcing, so should they reach sufficient scale then transformation to an efficient food system could occur rapidly.

\section{In conclusion}

The scale of total food system costs is only now becoming clear, as the data revolution allows for more transparent and more comprehensive analysis of the local and global impacts of the drive for cheaper calories. Much has been written about the need to reduce agriculture's environmental footprint and tackle the global obesity pandemic, but these problems should not be considered in isolation. We have argued that environmental degradation and obesity are both related outcomes of a dysfunctional food system that encourages the overconsumption of calories, excessive waste and the externalization of costs onto the environment and health system. A continued myopic focus on agricultural productivity risks perpetuating these problems: the productivity paradox means that increasing agricultural efficiency drives system inefficiency through increased waste, increased environmental costs and increased healthcare costs. A challenge for global development is that endeavouring to 'feed a world of 7-10 billion' in the way we are currently fed will create more problems than it solves through driving the vicious circle. As well as being unsustainable, this is iniquitous because the local and global poor disproportionately pay the costs levies on health and environment. Instead, we should change the narrative to empower people to invest in their nutrition for a healthy life, eating food that is supplied by a sustainable food system.

There is an urgent need to move the focus from thinking about agricultural productivity as a proxy for the outcomes society needs, and instead to focus fully on systemic productivity: people fed healthily and sustainably per unit input. In a finite world, we have no long-term option but to find ways to deliver a sustainable food system that provides healthy diets.

Author ORCIDs. (D) Tim G. Benton, 0000-0002-7448-1973; Rob Bailey, 0000-0001-6740-4868.

Acknowledgments. None.

Author contributions. T. G. B. developed the initial concept. T. G. B. and R. B. jointly wrote the paper.

Financial support. GCRF-AFRICAP BB/P027784/1.

Conflict of interest. None.

Publishing ethics. This research and article complies with Global Sustainability's publishing ethics guidelines. 


\section{Notes}

i Data from http://www.fao.org/faostat/en/\#data/OA

ii Data from World Bank http://data.worldbank.org/

iii https://www.ers.usda.gov/data-products/international-agricultural-productivity.aspx\#.U2TN6ijuymY

iv https://www.trumanlibrary.org/whistlestop/50yr_archive/inagural20-

jan1949.htm

v https://data.worldbank.org/indicator/NV.AGR.TOTL.ZS

vi Data from http://www.fao.org/faostat/en/\#data/OA

vii For example, G20 Agriculture Ministers' Declaration 2017 http://www.g20. utoronto.ca/2017/170122-agriculture-en.html; 2016 http://www.g20.utoronto. ca/2016/160603-agriculture.html

viii For example, see https:/uk.kantar.com/consumer/green/2017/veganism/ and https://www.bbc.co.uk/news/business-44488051

ix For example, see http://www.huffingtonpost.co.uk/entry/small-farms-localfood_us_589377fae4b07595d05a477f

x For example, the Climate Action 100+ group of institutional investors manages $\$ 33$ trillion in assets and is engaging with companies to take action on climate change and enhance disclosures on climate risk; the Taskforce on Climate-related Financial Disclosures of the G20's Financial Stability Board has produced guidance for disclosure on climate risks that is being adopted and developed by investors, corporations and governments; the World Bank recently announced its intention to end financing of upstream oil and gas, building on an earlier exit from coal power generation; a new network of central banks and supervisors for greening the financial system is cooperating to integrate sustainability into prudential supervision and regulatory frameworks.

\section{References}

Alexander, P., Brown, C., Arneth, A., Finnigan, J., Moran, D., \& Rounsevell, M. D. A. (2017). Losses, inefficiencies and waste in the global food system. Agricultural Systems, 153, 190-200. http://doi.org/10.1016/j. agsy.2017.01.014

Alexandratos, N., \& Bruinsma, J. (2012). World Agriculture Towards 2030/ 2050: the 2012 Revision. Retrieved from http://www.fao.org/3/a-ap106e.pdf

Amundson, R., Berhe, A. A., Hopmans, J. W., Olson, C., Sztein, A. E., \& Sparks, D. L. (2015). Soil and human security in the 21st century. Science, 348(6235), 1261071. http://doi.org/10.1126/science.1261071

Bahadur, K. C. K., Dias, G. M., Veeramani, A., Swanton, C. J., Fraser, D., Steinke, D., Lee, E., Wittmen, H., Farber, J. M., Dunfield, K., McCann, K., Anand, M., Campbell, M., Rooney, N., Raine, N. E., Van Acker, R., Hanner, R., Pascoel, S., Sherif, S., Benton, T. G., \& Fraser, E. D. G. (2018). When too much isn't enough: Does current food production meet global nutritional needs? PLoS One, 13(10), 16. http:// doi.org/10.1371/journal.pone.0205683

Bailey, R., Froggatt, A., \& Wellesley, L. (2014). Livestock - Climate Change's Forgotten Sector. London: The Royal Institute of International Affairs, Chatham House.

Bajželj, B., Allwood, J. M., \& Cullen, J. M. (2013). Designing climate change mitigation plans that add up. Environmental Science \& Technology, 47 (14), 8062-8069. http://doi.org/10.1021/es400399h

Bajzelj, B., Richards, K. S., Allwood, J. M., Smith, P., Dennis, J. S., Curmi, E., \& Gilligan, C. A. (2014). Importance of food-demand management for climate mitigation. Nature Climate Change, 4(10), 924-929. http://doi.org/10.1038/ nclimate2353

Baulcombe, D., Crute, I., Davies, B., Dunwell, J., Gale, M., Jones, J., Pretty, J., Sutherland, W., Toulmin, C., \& Green, N. (2009). Reaping the Benefits: Science and the Sustainable Intensification of Global Agriculture. London: The Royal Society.

Cassidy, E. S., West, P. C., Gerber, J. S., \& Foley, J. A. (2013). Redefining agricultural yields: from tonnes to people nourished per hectare. Environmental Research Letters, 8(3), 034015. Retrieved from http://stacks.iop.org/1748$9326 / 8 / \mathrm{i}=3 / \mathrm{a}=034015$

Cordero, P., Li, J., Temple, J. L., Nguyen, V., \& Oben, J. A. (2016). Epigenetic mechanisms of maternal obesity effects on the descendants. In L. R. Green, \& R. L. Hester (eds), Parental Obesity: Intergenerational Programming and Consequences (pp. 355-368). New York: Springer New York.
Dalin, C., Wada, Y., Kastner, T., \& Puma, M. J. (2017). Groundwater depletion embedded in international food trade. Nature, 543(7647), 700-704. http:// doi.org/10.1038/nature21403

Davis, K. F., Gephart, J. A., Emery, K. A., Leach, A. M., Galloway, J. N., \& D'Odorico, P. (2016). Meeting future food demand with current agricultural resources. Global Environmental Change, 39, 125-132. http://doi.org/10. 1016/j.gloenvcha.2016.05.004

Dorward, A. (2013). Agricultural labour productivity, food prices and sustainable development impacts and indicators. Food Policy, 39, 40-50. https:// doi.org/10.1016/j.foodpol.2012.12.003

Ercsey-Ravasz, M., Toroczkai, Z., Lakner, Z., \& Baranyi, J. (2012). Complexity of the international agro-food trade network and its impact on food safety. PLoS One, 7(5), e37810.

Eshel, G., Shepon, A., Makov, T., \& Milo, R. (2014). Land, irrigation water, greenhouse gas, and reactive nitrogen burdens of meat, eggs, and dairy production in the United States. Proceedings of the National Academy of Sciences, 111(33), 11996-12001.

FAO (2013). State of Food and Agriculture 2013: Food systems for better nutrition. Rome, Italy. Retreived from http://www.fao.org/publications/sofa/ 2013/en/

FAO (2015). Natural Capital Impacts in Agriculture: Supporting Better Business Decision-Making. Retrieved from http://www.fao.org/fileadmin/ templates/nr/sustainability_pathways/docs/Natural_Capital_Impacts_in_ Agriculture_final.pdf

Fuglie, K. (2015). Accounting for growth in global agriculture. Bio-based and Applied Economics, 4(3), 201-234.

Fuglie, K., Benton, T. G., Sheng, Y. E., Hardelin, J., Mondelaers, K., \& Lanborde, D. (2016). Metrics of Sustainable Agricultural Productivity. Retrieved from http://www.oecd.org/tad/events/G20\%20MACS\%20WP\% 20Ag\%20Productivity\%20Metrics\%204-26-2016_Final.pdf

Garnett, T., Appleby, M., Balmford, A., Bateman, I., Benton, T., Bloomer, P., Burlingame, B., Dawkins, M., Dolan, L., \& Fraser, D. (2013). Sustainable intensification in agriculture: premises and policies. Science, 341(6141), 33-34.

Harwatt, H., Sabaté, J., Eshel, G., Soret, S., \& Ripple, W. (2017). Substituting beans for beef as a contribution toward US climate change targets. Climatic Change, 143(1-2), 261-270. http://doi.org/10.1007/s10584-0171969-1

Hugenschmidt, C. E. (2016). Type 2 Diabetes, obesity, and risk for dementia: recent insights into brain insulin resistance and hypometabolism. Current Behavioral Neuroscience Reports, 3(4), 293-300. http://doi.org/10.1007/ s40473-016-0093-2

Jänicke, M., \& Jacob, K. (2004). Lead markets for environmental innovations: a new role for the nation state. Global Environmental Politics, 4(1), 29-46. http://doi.org/10.1162/152638004773730202

Khoury, C. K., Bjorkman, A. D., Dempewolf, H., Ramirez-Villegas, J., Guarino, L., Jarvis, A., Rieseberg, L. H., \& Struik, P. C. (2014). Increasing homogeneity in global food supplies and the implications for food security. Proceedings of the National Academy of Sciences, 111(11), 4001-4006.

Lebow, V. (1955). Price competition in 1955. Journal of Retailing, 31(1), 5-10. Liu, C., Kroeze, C., Hoekstra, A. Y., \& Gerbens-Leenes, W. (2012). Past and future trends in grey water footprints of anthropogenic nitrogen and phosphorus inputs to major world rivers. Ecological Indicators, 18(Supplement C), 42-49. https://doi.org/10.1016/j.ecolind.2011.10.005

McKeon, N. (2014). Food Security Governance: Empowering Communities, Regulating Corporations. Taylor \& Francis.

NCD-RisC (2016a). Trends in adult body-mass index in 200 countries from 1975 to 2014: a pooled analysis of 1698 population-based measurement studies with 19.2 million participants. The Lancet, 387(10026), 1377-1396.

NCD-RisC (2016b). Worldwide trends in diabetes since 1980: a pooled analysis of 751 population-based studies with 4.4 million participants. The Lancet, 387(10027), 1513-1530. https://doi.org/10.1016/S0140-6736(16) 00618-8

Newbold, T., Hudson, L. N., Arnell, A. P., Contu, S., De Palma, A., Ferrier, S., Hill, S. L. L., Hoskins, A. J., Lysenko, I., Phillips, H. R. P., Burton, V. J., Chng, C. W. T., Emerson, S., Gao, D., Pask-Hale, G., Hutton, J., Jung, M., Sanchez-Ortiz, K., Simmons, B. I., Whitmee, S., Zhang, H., Scharlemann, J. P. W., \& Purvis, A. (2016). Has land use pushed terrestrial 
biodiversity beyond the planetary boundary? A global assessment. Science, 353(6296), 288-291. https://doi.org/10.1126/science.aaf2201

OECD (2017). Agriculture Policy Monitoring and Evaluation 2017. Retrieved from http://www.oecd.org/tad/policynotes/Agricultural\%20Monitoring\% 20and\%20Evaluation\%202017.pdf

Paulot, F., \& Jacob, D. J. (2014). Hidden cost of U.S. agricultural exports: particulate matter from ammonia emissions. Environmental Science \& Technology, 48(2), 903-908. https://doi.org/10.1021/es4034793

Poore, J., \& Nemecek, T. (2018). Reducing food's environmental impacts through producers and consumers. Science, 360(6392), 987-992. https:// doi.org/10.1126/science.aaq0216

Porter, S. D., Reay, D. S., Higgins, P., \& Bomberg, E. (2016). A half-century of production-phase greenhouse gas emissions from food loss and waste in the global food supply chain. Science of the Total Environment, 571(Supplement C), 721-729. https://doi.org/10.1016/j.scitotenv.2016.07.041

Puma, M. J., Bose, S., Chon, S. Y., \& Cook, B. I. (2015). Assessing the evolving fragility of the global food system. Environmental Research Letters, 10(2), 024007.

Rocha, C. (2007). Food insecurity as market failure: a contribution from economics. Journal of Hunger \& Environmental Nutrition, 1(4), 5-22. https:// doi.org/10.1300/J477v01n04_02

Shepon, A., Eshel, G., Noor, E., \& Milo, R. (2016). Energy and protein feed-to-food conversion efficiencies in the US and potential food security gains from dietary changes. Environmental Research Letters, 11(10), 105002. Retrieved from http://stacks.iop.org/1748-9326/11/i=10/a=105002

Shepon, A., Eshel, G., Noor, E., \& Milo, R. (2018). The opportunity cost of animal based diets exceeds all food losses. Proceedings of the National Academy of Sciences, 115(15), 3804-3809. https://doi.org/10.1073/pnas.1713820115

Tait, C. (2015). Hungry for Change. The Final report of the Fabian Commission on Food and Poverty. London: Fabian Society.

Van Boeckel, T. P., Brower, C., Gilbert, M., Grenfell, B. T., Levin, S. A., Robinson, T. P., Teillant, A., \& Laxminarayan, R. (2015). Global trends in antimicrobial use in food animals. Proceedings of the National Academy of Sciences, 112(18), 5649-5654. https://doi.org/10.1073/pnas.1503141112

Wagner, K. H., \& Brath, H. (2012). A global view on the development of non communicable diseases. Preventive Medicine, 54, S38-S41. https://doi.org/ 10.1016/j.ypmed.2011.11.012

West, P. C., Gerber, J. S., Engstrom, P. M., Mueller, N. D., Brauman, K. A., Carlson, K. M., Cassidy, E. S., Johnston, M., MacDonald, G. K., \& Ray, D. K. (2014). Leverage points for improving global food security and the environment. Science, 345(6194), 325-328.

Williamson, J. (1990) What Washington means by policy reform. In J. Williamson (ed.), Latin American Adjustment: How Much Has Happened? (pp. 90-120). Washington: Institute for International Economics. 